\title{
HERBICIDE USE IN SASKATCHEWAN FORESTS: A MATTER OF VALUES*
}

J. STAN ROWE, Department of Crop Science and Plant Ecology, University of Saskatchewan, Saskatoon, Saskatchewan. S7N OW0

The intent of this brief is to get at the roots of some of the problems facing the Task Force, thereby bringing to the inevitable debate a better understanding of what motivates the opposing views. Consequently, the contents of this brief do not in all parts conform to the Terms of Reference of the Task Force, although they are relevant to the latter. In his news release of December 10, 1984, the then Minister of Parks and Renewable Resources stated that the Task Force report will shape government policy on the herbicide/forestry issue, which justifies the adoption here of a broad rather than a narrow perspective. I also argue against the use of herbicides as a forestry management tool.

\section{Facts and Values}

In all questions of individual and social action, values (whether expressed or not) set the direction. In those social circumstances where a concensus on action is speedily reached by agreement on facts, a parallel consensus in value judgments can be assumed. By the same token, strong differences of opinion as to appropriate action reflect conflicts in basic values that are commonly described as differences in philosophy, ideology, worldview, or paradigm. In such circumstances facts lose their significance as a means of reaching consensus, for the opposing sides sift, select, edit and marshal facts according to their congruity with whichever worldview or philosophy is held.
Our education system is remiss, or perhaps in a multicultural world we should label it naive, in not teaching that facts are secondary to deep beliefs. Facts are the dummy on the knee of the ventriloquist, saying what he wants them to. It is the interpretation of facts that is important, and in science as much as in politics, law, or commerce, meaning depends on a value framework. In common parlance, the Devil can also quote scripture.

Every Task Force and Board of Inquiry looking into environmental questions comes up against the tough truth that today two value systems are in conflict. For lack of better terms I will call them the humanistic-technological and the ecologicenvironmental. The first, the philosophy or religion of the majority, has dominated the western world for 500 years since the Rennaissance. Above all else it values human ingenuity as expressed in technological control and industrial growth. In essence and despite such flare-up warnings of limits to growth as acid rain, toxic pollution, soil erosion, and atmospheric change, it optimistically exempts humanity from ecological constraints. It believes that all problems can be overcome by more science and more technology of the power/control type.

The second view places high value on the world ecosystem as the one and only irreplaceable home of all life. Reemerging in

\footnotetext{
* This brief was prepared for presentation to a task force investigating the appropriateness and safety of herbicide use in forest management in Saskatchewan. The task force, chaired by Professor Don Rennie, Dean of Agriculture at the University of Saskatchewan, was approved by the Government of Saskatchewan in late 1984. The brief has been reproduced by the Saskatchewan Environmental Society as part of its "Backgrounder" series.
} 
the second half of the 20th century, this philosophy stems from an ancient preindustrial tradition with roots in many cultures of the world (including that of the Dene). It does not exempt humanity from the ecological necessities of fitting itself to the cycles and flows of this unique planet. Although it is not anti-science/technology, it recognizes the necessity of guiding science/technology toward worldpreserving and life-enhancing goals rather than assuming, as today, that whatever the market rewards is benign. In all questions of social directions it asks: Which alternative is most likely to contribute over the long term to a healthy, sustainable symbiosis between the organic world and the human race?

I am not suggesting that citizens of Saskatchewan are neatly polarized in two camps, accepting the one value system or the other. Many, probably most, are somewhere in between, trying to make the best of both. Nevertheless an understanding that the two viewpoints exist, that they are based on different evaluations of the world, and that they call on their believers to act in quite different ways, helps to explain what is often attributed to "emotionalism" or "irrationality" on either side. It explains why economists and ecologists are frequently at odds, why nuclear energy is embraced with joy or rejected with loathing, and why northern people living in a largely "bush economy" perceive proposed actions coming out of southern industrial society as threatening to their way of life.

\section{Herbicides and Vegetation Management}

Because the emerging ecologicenvironmental world-view seems to me to be the more realistic of the two so far as the future of humanity on this planet is concerned, my position is that as a general rule society ought to opt always for alternatives to the use of biocides in whatever management of organisms - plants or animals - is undertaken.

Biocides are designed to kill, and by their very nature they are unsafe. Biology has revealed that DNA ties all living things together; many homologies are apparent in the cell constituents of plants, animals, and ourselves. The short histories of supposedly non-injurious poisons show their distressing capacity to affect more than their designated targets. Alachlor is a recent example, cast in doubt by new tests that indicate it may be carcinogenic. Ethylene dibromide is another, banned in 1983 in the USA after 40 years of "safe" use. As reported by the US National Academy of Sciences, approximately 80 percent of some 600 generic pesticides in use have not been adequately studied for their risks in producing cancer, genetic changes, or birth defects $^{3}$ - presumably because such studies take a long time.

A second reason for avoiding toxins as tools for manipulating the ecosphere is the probability that even those pronounced safe (meaning staying and perishing with their targets) will act synergistically with other chemicals in the environment to produce unforeseen toxicities. Introducing new poisons into the chemical stew that already surrounds us risks multiplicative effects that are impossible to test for or predict; there are too many permutations and combinations. The mortality of trees in the Black Forest of Germany seems to be an as yet unexplained synergism between acid rain and other industrial toxins. No agency can possibly pre-test, for example, the effects of forest herbicides in combination with Alberta-released $\mathrm{SO}_{2}$.

Roundup is reputed to be a relatively safe herbicide, although the fraudulent IBT tests, the secret Monsanto tests (proprietary and therefore not released), and at least one report of a suspected carcinogen associated with glyphosate, ${ }^{1}$ raise legitimate doubts as to its side-effects. Also still unanswered are questions as to its effect on water bodies and on such hydrologically important communities as Sphagnum bogs and sedge fens.

Sutton's recent article on the use of glyphosate in Ontario under conditions similar to those in the Mixedwood forest of 


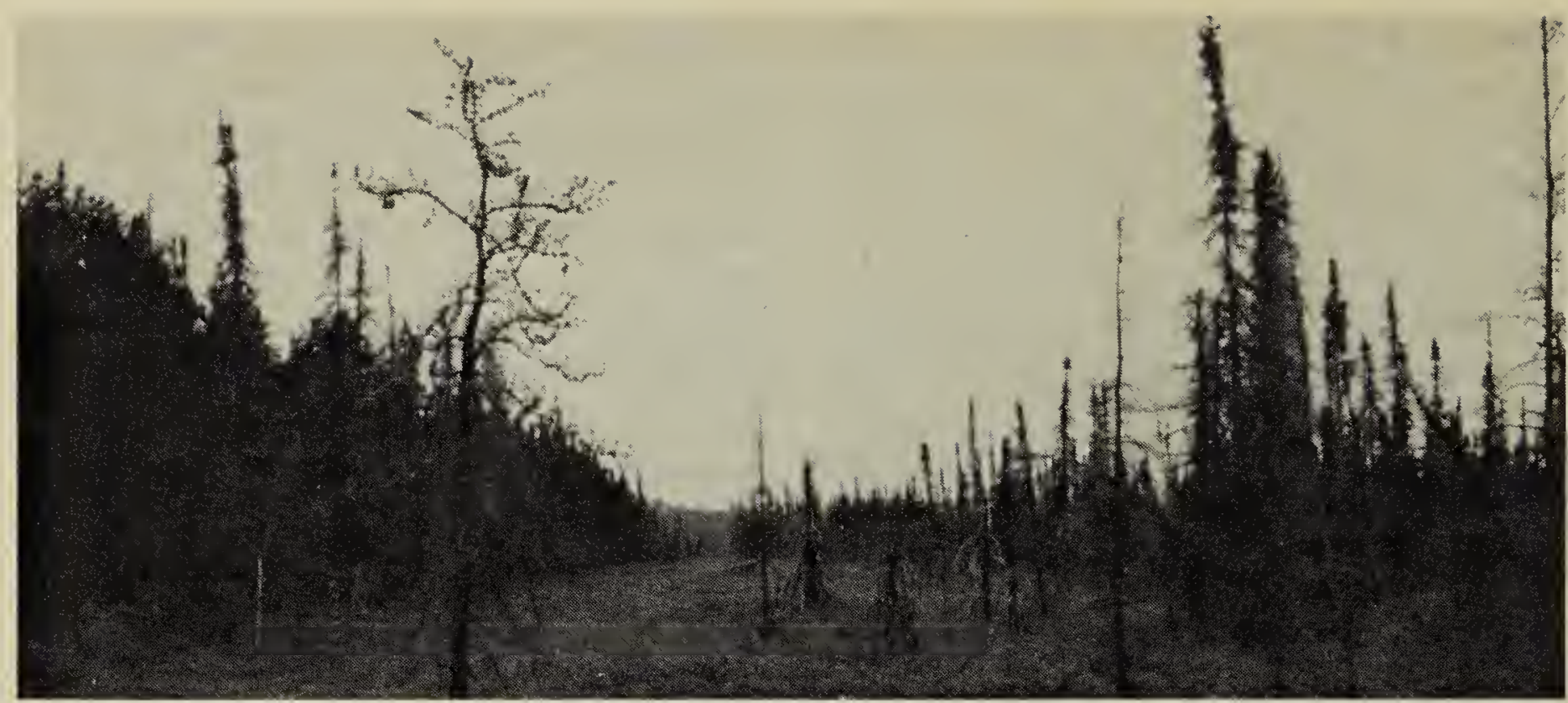

Signal Point

Wapawekka Lake, Saskatchewan

Chris Adam

Saskatchewan makes the important point that "Success in controlling non-crop vegetation does not necessarily mean that crop trees will subsequently perform well." ${ }^{\prime 2}$ Although competitors such as aspen were killed by glyphosate treatments, the opening of the vegetations invited rodent damage and bud-freezing of the white spruce seedlings. Neither did the herbicide treatments benefit jack pine seedlings. For a variety of reasons, too great a success in weed control can be detrimental to the supposed beneficiaries in the non-agricultural forestry setting.

The above is not meant to identify as a central issue the safety and efficacy of Roundup. If, as happened with 2, 4,5-T, Roundup were to be banned for whatever reason, Monsanto or Ciba-Geigy would soon have ready another candidate herbicide guaranteed to do the job swiftly, efficiently, and safely. The important question is not which poison, but whether the biocide route is the way to go in the an organic world already suffering from a surfeit of toxins? I believe that R \& D money should resolutely be diverted to safer alternatives, and that the safety factor should always be a major weight in cost/benefit evaluations of plantation management.

\section{Land Use and Forest Management Plans in Northern Saskatchewan}

It is difficult if not impossible to find good answers to questions of detail, especially technologic questions such as whether or not to use herbicides, when the larger picture and context of land use is unclear. The Task Force is addressing a small part of a large social problem having to do with rights to the use of the land, and with how forestry is to be integrated in a multiple land-use framework.

In south Saskatchewan a farmer owns his land and has the undisputed right to spray biocides around as he pleases. If he inadvertently poisons such non-target organisms as his family and himself, that is pretty much his affair (though the long-term social costs may be great). By contrast, the forested lands of the north are public (crown) lands, leased for forestry purposes but not owned by the forest industry. As custodian, the government must consider other claims on the land than those of the forest industry. Does herbicide spraying to release conifer seedlings fit into the larger picture of land uses that include along with recreation, tourism and wildlife management the so-called "bush economy" of fishing, hunting, trapping, and berry picking? In my view it does not.

The intention, in one report I have seen, is to treat with herbicides each year about one-fifth of the annual cut-over area. Such an on-going program would soon subject an appreciable area to the largely unfore- 
seen consequences of depleting the broadleaf vegetation. The character of the forest will be changed in a patchwise fashion as non-seeding (vegetavely reproducing) species are killed, rare plants exterminated, and plants with early dormancy or other mechanisms of resistance are selected as weedy survivors. Will the replacement of aspen by willows be counted an advance? No one can say without invoking a land use plan that prescribes the full range of legitimate uses, nor can anyone say without thinking hard about the future (when aspen may be Saskatchewan's most valuable tree).

Within a broad land-use framework, forestry will continue to be an important part of the economy of the north and establishment of future forests after clearcutting will continue to be the major management problem. Alternatives to chemical weeding may be found, in part, through silvicultural planning.

Foresters recommend prompt planting after logging, before strong competition develops. Use of large planting stock, and preparation of site by surface scarification, are techniques that assist the establishment and the competitiveness of planted seedlings. Of equal importance is the matching of species to site, for planting jack pine on clay-loam tills and other such aspen sites is simply to ask for competitive trouble. Use of a good site classification with soil maps that identify surficial materials by texture, drainage, and $\mathrm{pH}$, can help to avoid off-site plantings.

Nevertheless, without fire that was the normal regenerator of Saskatchewan forests, problems of competition are unavoidable on the richer conifer sites, and here manual release is probably the only feasible alternative to the use of herbicides. The techniques are familiar to foresters and there are many good tools for the job. Just such a project is going on in the Hudson Bay forest district this winter, described as a Forestry Improvement Program in DPRR's News Release 85-022, 11 January 1985.
Arguments against manual cleaning of plantations are economic; the costs are said to be too high for the projected benefits. In such calculations much depends on the social and time frameworks within which the benefits are calculated. The benefits of preserving farmland against its alienation for other uses are low or high depending on whether the judgment is that of the individual with his eye on retirement or that of society with its eye on good food for the next ten, twenty or more generations. Similarly, in forestry are benefits to be judged in the narrow framework of fast, cheap wood growth or by reference to a broader and longer term range of environmental values? The social benefits of enlisting the people of the north as husbanders of the forest in ways of which they approve are incalculable, and hence do not fit the traditional cost/benefit calculations.

The people of northern Saskatchewan are in dire straits, with unemployment running at 60-80 percent. Many feel that as long as they have access to the natural forests they can survive economic hardships. Industrial forestry is perceived as a real threat to their livelihood. It is important that (1) they be sympathetic to forest management techniques and that (2) they benefit from use of the forest resource. On both counts the proposed use of herbicides should be rejected in favour of more environmentally benign and more labour intensive methods of forest management.

1 KHAN, S. and J.C. YOUNG. N-nitrosamine formation in soil from the herbicide Glyphosate. Journal of Agricultural Food Chemistry 25(6):1430-1432.

2 SUTTON, R.F. 1984. Plantation establishment in the Boreal Forest: Glyphosate, Hexazinone, and manual weed control. Forestry Chronicle 60:283-287.

3 WEIS, J.S. 1984. Pesticide policies change slowly. BioScience 34(9):549. 